\title{
AMMONIA VOLATILIZATION OF UREA IN THE OUT-OF-SEASON CORN ${ }^{(1)}$
}

\author{
Hamilton Seron Pereira ${ }^{(2)}$, Anabelisa Ferreira Leão ${ }^{(3)}$, Adriana \\ Verginassi $^{(3)} \&$ Marco Aurélio Carbone Carneiro ${ }^{(2)}$
}

\begin{abstract}
SUMMARY
The aim of this study was to evaluate the $\mathrm{N}$ losses due to volatilization at different rates of common urea, polymer coated urea and urease inhibitor-treated urea in the out-of-season corn, using semi-open static collectors. The treatments consisted of $\mathrm{N}$ levels on side-dressing fertilization with urea in different treatments: (a) control (without $\mathrm{N}$ ), (b) urea $40 \mathrm{~kg} \mathrm{ha}^{-1} \mathrm{~N}$, (c) urea $80 \mathrm{~kg} \mathrm{ha}^{-1} \mathrm{~N}$, (d) polymer coated urea $40 \mathrm{~kg} \mathrm{ha}^{-1} \mathrm{~N}$, (e) polymer coated urea $80 \mathrm{~kg} \mathrm{ha}^{-1} \mathrm{~N}$ and (f) urea with the urease inhibitor (UI) $\mathrm{N} 80 \mathrm{~kg} \mathrm{ha}^{-1} \mathrm{~N}$. The results showed that the treatments with polymer coated urea and with urease inhibitor-treated urea reduced the volatilization of $\mathrm{N}$ around $50 \%$ compared to common urea, either in the first and the second $\mathrm{N}$ side-dressing fertilizations. Thus, they demonstrate that the polymer coat and the urease inhibitors were effective in reducing the volatilization of urea $\mathrm{N}$ applied in coverage, which resulted in higher productivity. There was also increasing urease activity in the treatments with application of common urea.
\end{abstract}

Index terms: nitrogen, nitrogen fertilization, slow release.

\section{RESUMO: VOLATILIZAÇÃO DE AMÔNIA DA UREIA NA CULTURA DO MILHO SAFRINHA}

Oobjetivo deste estudo foi avaliar as perdas por volatilização doN em diferentes doses de ureia comum, revestida com polímeros e tratada com inibidores de urease na cultura do milho safrinha, utilizando coletores semiabertos estáticos. O N, na forma de ureia, foi aplicado em cobertura nas seguintes doses: milho safrinha solteiro (sem N); ureia - $40 \mathrm{~kg} \mathrm{ha}^{-1}$ de $\mathrm{N}$; ureia $80 \mathrm{~kg} \mathrm{ha^{-1 }}$ de $\mathrm{N}$; ureia revestida com polímeros - $40 \mathrm{~kg} \mathrm{ha}^{-1}$ de $\mathrm{N}$; ureia revestida com polímeros

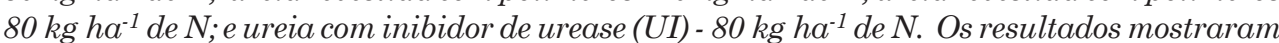

\footnotetext{
(1) Parte da Tese de Mestrado do segundo autor apresentada ao Centro de Ciências Agrárias e Biológicas, Universidade Federal de Goiás, UFG, Campus Jataí. Recebido para publicação em abril de 2009 e aprovado em outubro de 2009.

(2) Professor Adjunto da Agronomia, Campus Jataí da Universidade Federal de Goiás-Jataí. Caixa Postal 03, CEP 75804-020 Jataí (GO). E-mails: hseron@uol.com.br; carbonecarneiro@yahoo.com.br

(3) Pós-Graduandos do Programa de Pós-Graduação em Agronomia, Campus Jataí da Universidade Federal de Goiás. Rod. BR 364, km 192, Jataí-GO. Bolsista CAPES. E-mails: anabelisaleao@hotmail.com; driverginassi@gmail.com
} 


\begin{abstract}
que os tratamentos com ureia revestida e ureia com inibidor de urease reduziram a volatilização de $\mathrm{N}$ em torno de $50 \%$ em relação à ureia comum, tanto na primeira quanto na segunda cobertura nitrogenada. Foi demonstrado que o revestimento da ureia e o inibidor da urease foram eficientes na redução da volatilização do $\mathrm{N}$ da ureia aplicados em cobertura, o que refletiu em maiores produtividades. Verificou-se também maior atividade da urease nos tratamentos com aplicação de ureia comum.
\end{abstract}

Termos de indexação: nitrogênio, adubação nitrogenada, liberação lenta.

\section{INTRODUCTION}

In 2007, corn crops occupied about 12.9 millions ha in Brazil, with an average yield of 3,298 $\mathrm{kg} \mathrm{ha}^{-1}$ in the normal season and $2,907 \mathrm{~kg} \mathrm{ha}^{-1}$ out-of-season (Conab, 2007). Being one of the main inputs in the productive field, corn is used in animal feeding, especially in swine, poultry and dairy cattle breeding. In human nutrition, it participates as the raw material for around 600 industrial products.

Regarding on nutrient demand by the cultures, $\mathrm{N}$ is the most demanded nutrient when it comes to quantity. This fact is shown in the worldwide consumption of the nutrient in fertilizers, overcoming the used quantities of $\mathrm{P}$ and $\mathrm{K}$ (Malavolta, 2006). The large demand for $\mathrm{N}$ makes the corn crop highly responsive to $\mathrm{N}$ fertilization. Moreover, in soils with high fertility or in limed soils, N, which usually does not accumulate in forms readily available in the soil, controls the levels of productivity of corn grains.

Nitrogen fertilizers present high solubility and are effective for corn crops, attending each fertilizer's specificities (Cantarella \& Raij, 1986). Urea is characterized as the granulated solid fertilizer of highest $\mathrm{N}$ concentration (45 \%) in amide form. Among the sources of $\mathrm{N}$, it has lower market value and is the most used. Therefore, there is some concern regarding on its use due to the fact that its application on surface promotes $\mathrm{N}$ losses by volatilization in the form of $\mathrm{N}$ $\mathrm{NH}_{3}$, even in acid soils. Among the advantages of urea, besides the high $\mathrm{N}$ concentration and low cost, one may mention the low expenses with transportation, storage and application, high solubility, low corrosive properties as well as easiness to mix with other sources (Melgar et al., 1999).

The volatilization process involves, at first, urea hydrolysis through urease. Urease is an extracellular enzyme produced by several soil microorganisms or plant residues. Many factors affect its hydrolysis, such as: temperature, humidity, gas exchange, water evaporation rate, water content in the soil, $\mathrm{pH}$, buffering capacity, cation exchange capacity and textural class (Freney et al., 1985; Hargrove, 1988; Byrnes, 2000).

Several modifications have been done to urea in order to increase its efficiency and decrease $\mathrm{N}$ losses by volatilization, for instance: coverage with elementary sulphur and polymers, addition of acids and salts to avoid ammonia formation and mixture with other fertilizers (Cantarella, 2007). Coated fertilizers include soluble composts covered with a semi-permeable membrane, which controls the liberation of nutrients into the culture medium (Bennett, 1996). Urease inhibitors are composts which, when added to urea, decrease the urease activity, delaying the hydrolysis of the fertilizer. Consequently, there is more time for urea to diffuse from the place of application, either due to the rain or to irrigation water, reducing losses by volatilization of ammonia (Contin, 2007).

Coating of urea might be done with several products, and the use of polymers has been an option studied for many years. Polymers organize themselves on the surface of granules forming a protecting and semi-permeable coat which allows for the gradual solubility of the nutrient. The product KimCoat LGU is a polymer-coated urea with high charge density (NutriSphere-Nou NSN), which presents three layers of polymers covering the urea grain (Reis Jr., 2007).

NBPT [N-(n-butyl) thiophosphoric acid triamide] is now the most promising urease inhibitor. It has been tested in some countries with generally satisfactory results. NBPT is efficient in low concentrations, and it inhibits urea hydrolysis for periods between three and 14 days depending on soil temperature, humidity and other environmental conditions. Furthermore, its application has not shown any effect over the soil biological proprieties, which contributes for making its use quite viable (Cantarella \& Marcelino, 2007).

In this context, the aim of this study was to evaluate the losses due to $\mathrm{N}$ volatilization at different rates of common urea, polymer coated urea and urease inhibitor-treated urea in the out-of-season corn (also known in Brazil as off-season corn or "safrinha" corn), using semi-open static collectors.

\section{MATERIAL AND METHODS}

The experiment was carried out in Jataí - GO, in an Oxisol or Rhodic Hapludox soil (Dystroferric Red Latosol) with the following chemical characteristics: $\mathrm{pH}\left(\mathrm{H}_{2} \mathrm{O}\right)$ : 6.43; $\mathrm{P}\left(\mathrm{mg} \mathrm{dm}^{-3}\right)$ : 13 (extracted by $\mathrm{H}_{2} \mathrm{SO}_{4}$ 
$\left.0.025 \mathrm{~mol}_{\mathrm{c}} \mathrm{dm}^{-3}+\mathrm{HCl} 0.05 \mathrm{~mol}_{\mathrm{c}} \mathrm{dm}^{-3}\right) ; \mathrm{Al}^{3+}\left(\mathrm{mmol}_{\mathrm{c}} \mathrm{dm}^{-3}\right):$ $0.3 ; \mathrm{Ca}^{2+}\left(\mathrm{mmol}_{\mathrm{c}} \mathrm{dm}^{-3}\right): 37.1 ; \mathrm{Mg}^{2+}\left(\mathrm{mmol}_{\mathrm{c}} \mathrm{dm}^{-3}\right): 12.9$; Sum of bases $\left(\mathrm{mmol}_{\mathrm{c}} \mathrm{dm}^{-3}\right): 53.5 ; \mathrm{H}+\mathrm{Al}\left(\mathrm{mmol}_{\mathrm{c}} \mathrm{dm}^{-3}\right)$ : 45.7; CTC $\left(\mathrm{mmol}_{\mathrm{c}} \mathrm{dm}^{-3}\right): 99.2 ; \mathrm{V}(\%): 54$; and $\mathrm{OM}$ $\left(\mathrm{g} \mathrm{kg}^{-1}\right): 20.9$. The out-of-season corn sowing was done mechanically with a seeder-machine on February $16^{\text {th }}$ 2007, using the hybrid 30S40. The basic fertilization at the sowing time, into the furrows, was done with $300 \mathrm{~kg} \mathrm{ha}^{-1}$ of MAP (33 kg ha-1 of N and $147 \mathrm{~kg} \mathrm{ha}^{-1}$ of $\left.\mathrm{P}_{2} \mathrm{O}_{5}\right)$ and $100 \mathrm{~kg} \mathrm{ha}^{-1}$ of $\mathrm{KCl}\left(60 \mathrm{~kg} \mathrm{ha}^{-1}\right.$ of $\left.\mathrm{K}_{2} \mathrm{O}\right)$. The data regarding rainfall and temperature during the experimental period are available in figure 1.

Six treatments were used: T1- control (without N), $\mathrm{T} 2$ - urea, $40 \mathrm{~kg} \mathrm{ha}^{-1} \mathrm{~N}, \mathrm{~T} 3$ - urea, $80 \mathrm{~kg} \mathrm{ha}{ }^{-1} \mathrm{~N}, \mathrm{~T} 4$ polymer coated urea, $40 \mathrm{~kg} \mathrm{ha}^{-1} \mathrm{~N}$, T5 - polymer coated urea, $80 \mathrm{~kg} \mathrm{ha}^{-1} \mathrm{~N}$ and T6) urea with the urease inhibitor (UI), $\mathrm{N} 80 \mathrm{~kg} \mathrm{ha}^{-1} \mathrm{~N}$. The treatments were distributed in a complete randomized block design with four replications, summing up 24 plots. Each experimental plot consisted of 10 rows of corn spaced $0,75 \mathrm{~m}$ apart and $9 \mathrm{~m}$ long. The evaluations were carried out in the medium third (central $3 \mathrm{~m}$ ) of the four central rows of each plot (main plot of $9 \mathrm{~m}^{2}$ ). Three meters at the rows ends and three rows in each lateral of the plots were considered borders.

The rate of $80 \mathrm{~kg} \mathrm{ha}^{-1} \mathrm{~N}$ used in the side-dressing fertilization was determined due to the expectations of the crop yield and to the historicity of the field, where the no-tillage system has been used for ten years in succession to soybean culture. It was observed that this rate has been often used by the corn producers in that region. Due to some operational limitations, the urease inhibitor (UI) $\mathrm{N} 40 \mathrm{~kg} \mathrm{ha}^{-1} \mathrm{~N}$ treatment was excluded.

The treatments were applied manually in rows, $5 \mathrm{~cm}$ beside the planting line in an area of $10 \mathrm{~cm}$, dividing the established doses in two side-dressing fertilizations (Figure 1). The first one was carried out 20 days after seedling emergence, when the corn crop presented six leaves and the second one 50 days after seedling emergence, when the crop presented around 12 leaves.

The semi-open static collection chambers for determination of $\mathrm{N}-\mathrm{NH}_{3}$ gas losses were settled in the field, in the middle of the plot of each treatment (Figure 2), near to the planting line where the sidedressing fertilizers were applied. To verify the volatilized ammonia captured by the chambers, two fertilizations were applied to the soil inside them, in previously weighed quantities of fertilizer, with the doses corrected for the chamber area simulating the fertilized area.

After applying the treatments, polyurethane plastic foam discs as static ammonia absorbers embedded in diluted phosphoric acid $0.7 \mathrm{~mol} \mathrm{~L}^{-1}$ and glycerol $5 \%$ $(\mathrm{v} / \mathrm{v})$ were put in the semi-open static chambers.

Up to the third day after the $\mathrm{N}$ application, the collections by the absorbent foam discs were done with $24 \mathrm{~h}$ intervals. After the third day of the $\mathrm{N}$ fertilization, the collections started being done every $48 \mathrm{~h}$. Thus, seven foam disc collections were done (1, $2,3,5,7,9$, and 11 days after the preflood fertilizer $\mathrm{N}$ application).

In the collections, the sorbers were changed, keeping only the disc in the lower position for $\mathrm{N}$ extraction and analysis. During the management of the sorber in the field as well as in the laboratory, in order to minimize the risks of contamination, rubber gloves and plastic bags to isolate the foams from the atmosphere were used. During the whole collection period, replacement of rain water in the soil inside the chambers was not done. The chambers were covered all the time, being the galvanized cap taken out for a few minutes only to change the foam, avoiding thus that rain water would affect the solubility of the

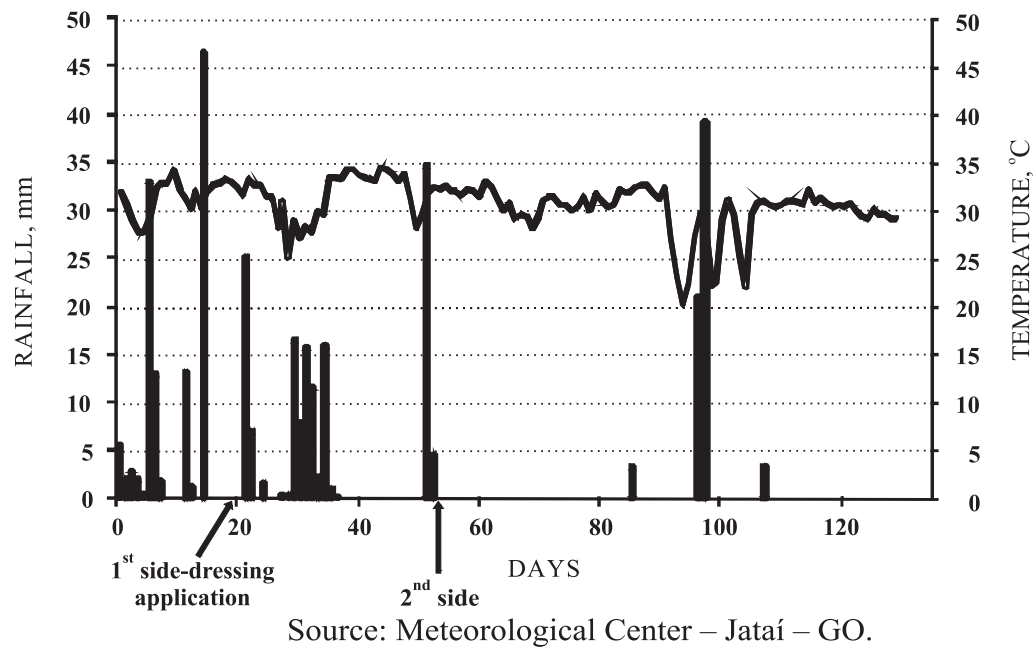

Figure 1. Temperature and rainfall during the experimental period. 


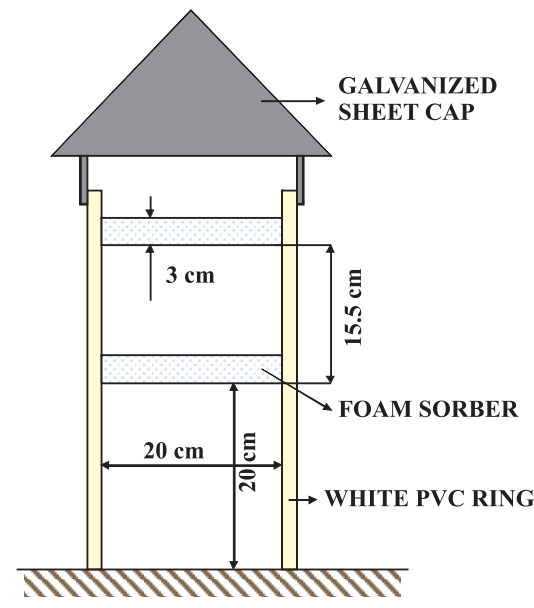

Adapted from Nommki (1973).

Figure 2. Semi-open static collection chamber for determination of $\mathrm{N}-\mathrm{NH}_{3}$ gas losses.

fertilizers. Therefore, this solubility was subject exclusively to the effect of soil moisture. These measures to minimize the microclimate effect within the chamber aimed at the creation of a highly favorable environment for urea volatilization.

The $\mathrm{N}-\mathrm{NH}_{3}$ retained in the sorbers was extracted by washing them (an average of five washes) with $\mathrm{KCl} 1 \mathrm{~mol} \mathrm{~L}^{-1}$ solution until reaching the volume of $500 \mathrm{~mL}$. A $50 \mathrm{~mL}$ aliquot of the $\mathrm{KCl} 1 \mathrm{~mol} \mathrm{~L}^{-1}$ extract was steam distilled and added with $\mathrm{NaOH}$ to increase the solution $\mathrm{pH}$ to 7.5. Distillation was performed in a micro-Kjeldhal distiller. The distillate was put in Erlenmeyer flasks with $10 \mathrm{~mL}$ of boric acid, $2 \%$ (w/v) aqueous solution with mixed indicator, and then titrated with $0.0025 \mathrm{~mol} \mathrm{~L}^{-1}$ sulfuric acid, according to the method described by Tedesco et al. (1995).

The volatilized ammoniacal $\mathrm{N}$ was calculated with the values of the sulfuric acid volumes spent in titration, in the blank tests and in the samples, using the following equation:

$$
\mathrm{N}=(\mathrm{Vs}-\mathrm{Vb}) \times \mathrm{f}
$$

where $\mathrm{N}=\mathrm{N}$ mg per chamber; $\mathrm{Vs}=$ acid volume spent in titrating the sample; $\mathrm{Vb}=$ acid volume spent in titrating the blank; and $\mathrm{f}=0.7$ (factor concerning the acid molarity, the aliquot volume and the extract in the volumetric flask). Posteriorly, the results were corrected according to the equations proposed by Lara Cabezas et al. (1999). Thus, it was obtained the daily volatilization rate (DVR) and the accumulated volatilization rate (AVR), calculated as the sum of the daily rates, for each sidedress application, and the sum of the two applications.

Avoiding the lateral rows of the plots, at the beginning of the corn blooming period it was performed the random collection of 15 leaves per plot for later determination of $\mathrm{N}, \mathrm{P}, \mathrm{K}, \mathrm{Ca}, \mathrm{Mg}, \mathrm{Cu}, \mathrm{Fe}, \mathrm{Mn}$ and $\mathrm{Zn}$ concentrations in the leaf tissue. To determine the nutrients in the leaves, only $30 \mathrm{~cm}$ of their central part were used, discarding the midrib. After the collection, the leaves were conditioned in paper bags and put in a forced-air circulation incubator to be dried at $60{ }^{\circ} \mathrm{C}$ to a constant weight. After drying, the samples were ground in a Wiley mill. Nitrogen was extracted by sulfuric digestion and the analytical determination was performed according to the method described by Malavolta et al. (1997).

Three soil collections were performed in the planting line, in the first, third and fifth day after the second side-dressing fertilization, to determine the urease activity. Three samples were collected in each treatment to form a composite sample, at the 0-10 cm depth layer. Determination of urease was done according to the method described by Tabatabai \& Bremner (1972).

In the harvest, performed on $20^{\text {th }}$ June 2007 (124 days after sowing), the following production components were assessed: hundred grains mass, first ear insertion height, average ear size and productivity. All the ears from the main plot were collected, weighed, measured and put in a mechanical thrasher. The grains were weighed and data was transformed in $13 \%$ wet basis.

Data was submitted to analysis of variance. Differences among means were compared by the Duncan test at the 0.05 probability level.

\section{RESULTS AND DISCUSSION}

Ammonia volatilization was influenced by the soil moisture conditions during the period when the sidedressing fertilizations were performed. In the first side-dressing application, when the soil was drier (Figure 1), the highest volatilization occurred between the fourth and fifth day after the application (Figure 3a), whereas in the second side-dressing application, with a more humid soil, the highest volatilization occurred between the first and second day after the side-dressing fertilization (Figure 4a). Ammonia losses and the influence of moisture over sugarcane trash up to the sixth day after $\mathrm{N}$ fertilization in field conditions were verified by Costa et al. (2003). Primavesi et al. (2001) observed N-NH 3 losses for urea volatilization between 1.1 to $52.9 \%$ depending on the urea rate applied and on the climatic conditions (temperature and moisture), in each evaluation period.

The T3 treatment (urea, $80 \mathrm{~kg} \mathrm{ha}^{-1} \mathrm{~N}$ ) was the one which presented the highest $\mathrm{N}-\mathrm{NH}_{3}$ volatilization in each collection, statistically differing from the other treatments in the three first days of collection (Figure 3a). Evaluating the curves, it is also possible 
to notice that the T6 treatment (urea with the urease inhibitor (UI) N $80 \mathrm{~kg} \mathrm{ha}^{-1} \mathrm{~N}$ ) presented a slower $\mathrm{N}$ $\mathrm{NH}_{3}$ liberation in the first collections. Nevertheless, as time went by, volatilized $\mathrm{N}-\mathrm{NH}_{3}$ values increased, overcoming all the treatments from the ninth day on, indicating the urease inhibitor action and showing that in the T6 treatment urea was available in the soil for a longer period. Cantarella et al. (1999) verified that when the rain was not sufficient to incorporate urea into the soil, $\mathrm{N}-\mathrm{NH}_{3}$ losses were heavier, and higher moisture accelerates the volatilization rates. However, if there was enough rain to incorporate urea, the volatilization level was kept low. Therefore, it is possible to conclude that, in field conditions, inhibitor treated urea might be advantageous, as it is exposed for a longer period to rainfall conditions to incorporate it before it reaches the volatilization peak.

At the end of the collection period, volatilization decreased in all the treatments and, in the accumulated ammonia volatilization loss rate, the $\mathrm{T} 5$ Treatment reduced N-NH${ }_{3}$ volatilization at $50 \%$ when compared to the highest rate of urea (T3). The T2, $\mathrm{T} 4$ and $\mathrm{T} 6$ treatments volatilized values similar to T5, not differing among themselves, but they differed from T3 (Figure 3b).

In the second side-dressing fertilization, the treatments were similar (Figure 4). Besides having the occurrence of the volatilization peak on the second day (Figure 4a), the moisture conditions also contributed for an increase in $\mathrm{N}-\mathrm{NH}_{3}$ volatilization.
In the period of the second side-dressing fertilization, it was possible to verify that volatilized $\mathrm{N}-\mathrm{NH}_{3}$ was doubled in the treatments, when compared to the volatilization occurred in the first fertilization. The origin of this fact might be the increase of soil $\mathrm{pH}$ due to higher urea hydrolysis caused by higher moisture in that application, which would favor $\mathrm{N}-\mathrm{NH}_{3}$ losses (Oliveira et al., 2007). After that period, losses decrease likely as a consequence of decrease of soil $\mathrm{pH}$ associated to $\mathrm{OH}^{-}$consumption during ammonia volatilization and nitrification (Whitehead, 1995).

As it occurred in the first side-dressing fertilization, T3 treatment (urea, $80 \mathrm{~kg} \mathrm{ha}^{-1} \mathrm{~N}$ ) differed significantly from the other treatments from the first to the fifth collection day, being overcome by T6 treatment in the collections of the seventh, ninth and eleventh day, which differed statistically from the other treatments (Figure 4).

Treatments T5 and T6 reduced significantly the $\mathrm{N}-\mathrm{NH}_{3}$ volatilization, when compared to T3 treatment (Figure 4b), confirming the effect of the two products (polymers and urease inhibitor) used to reduce $\mathrm{N}-\mathrm{NH}_{3}$ volatilization.

In the second side-dressing fertilization, T3 treatment volatilized twice the amount of $\mathrm{N}-\mathrm{NH}_{3}$ volatilized in the first fertilization and presented significant difference when compared to the other treatments regarding $\mathrm{N}-\mathrm{NH}_{3}$ accumulation in all the experimental period. The T5 and T6 treatments (a)

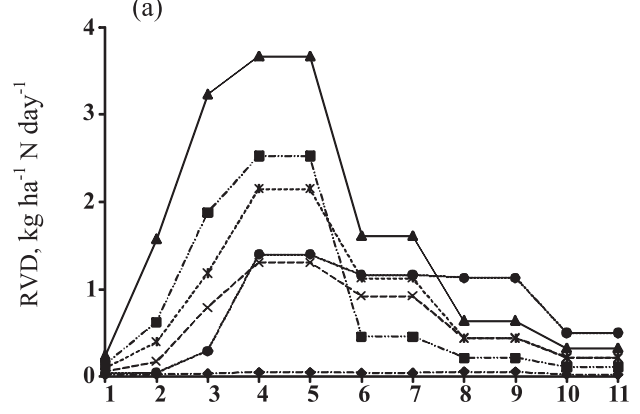

DAYS AFTER APPLICATION

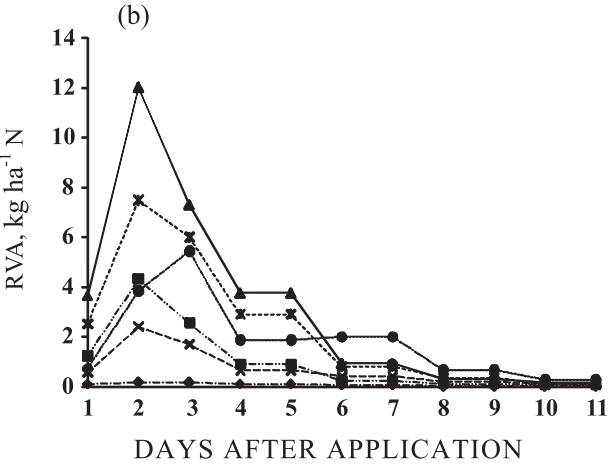

$-x-\mathrm{T} 4 \quad--*-\mathrm{T} 5 \longrightarrow-\mathrm{T} 6$

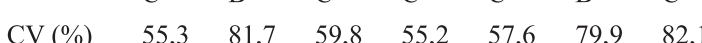

\begin{tabular}{llllllll}
\hline Day & 1 & 2 & 3 & 5 & 7 & 9 & 11 \\
& A & A & A & A & A & A & A \\
& B & B & B & B & B & B & B \\
& BC & B & BC & BC & B & B & B \\
& C & B & BC & CD & C & B & B \\
& C & B & C & CD & C & B & B \\
& C & B & C & D & D & C & C \\
CV $(\%)$ & 55,3 & 76,7 & 63,3 & 43,5 & 41,0 & 41,3 & 42,1
\end{tabular}

(1) The letters follow the order in which the points appear in the graphic in a top down direction, that is: the first line in the table refers to the highest points in the graphic of the collection days. The same letters on the same column did not differ significantly from each other, according to the Duncan test at $\mathrm{p} \leq 0.05$.

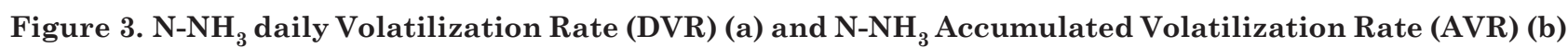
based on the treatments applied in the first side-dressing fertilization, 20 days after corn emergence. 

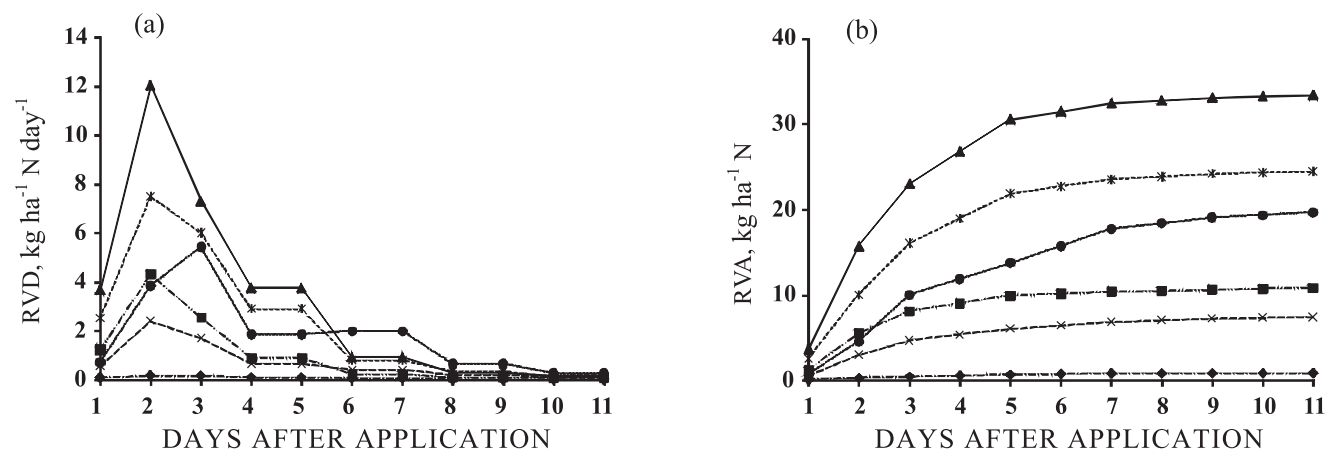

\begin{tabular}{|c|c|c|c|c|c|c|c|c|c|c|c|c|c|c|c|}
\hline & & & $-\triangleleft-\mathrm{T}$ & $\rightarrow$ & $\mathbf{T} 2$ & $-\mathrm{T} 3$ & $-x-\mathrm{T} 4$ & $--*-$ T5 & $-\mathrm{T} 6$ & & & & & & \\
\hline \multirow[t]{7}{*}{ Day } & $1^{(1)}$ & 2 & 3 & 5 & 7 & 9 & 11 & Day & 1 & 2 & 3 & 5 & 7 & 9 & 11 \\
\hline & A & $\mathrm{A}$ & $\mathrm{A}$ & A & $\mathrm{A}$ & A & $\mathrm{A}$ & & $\mathrm{A}$ & $\mathrm{A}$ & A & $\mathrm{A}$ & $\mathrm{A}$ & A & A \\
\hline & B & B & B & B & B & B & B & & B & B & B & B & B & B & B \\
\hline & $\mathrm{C}$ & $\mathrm{C}$ & B & $\mathrm{C}$ & B & B & B & & $\mathrm{C}$ & $\mathrm{C}$ & $\mathrm{C}$ & $\mathrm{C}$ & $\mathrm{C}$ & $\mathrm{C}$ & $\mathrm{C}$ \\
\hline & $\mathrm{C}$ & $\mathrm{C}$ & $\mathrm{C}$ & D & B & $\mathrm{BC}$ & $\mathrm{BC}$ & & $\mathrm{C}$ & $\mathrm{C}$ & $\mathrm{C}$ & D & D & D & D \\
\hline & $\mathrm{C}$ & $\mathrm{CD}$ & $\mathrm{C}$ & D & B & $\mathrm{BC}$ & $\mathrm{BC}$ & & $\mathrm{C}$ & $\mathrm{CD}$ & D & $\mathrm{E}$ & $\mathrm{E}$ & $\mathrm{E}$ & $\mathrm{E}$ \\
\hline & $\mathrm{C}$ & $\mathrm{D}$ & $\mathrm{D}$ & $\mathrm{E}$ & B & $\mathrm{C}$ & $\mathrm{C}$ & & $\mathrm{C}$ & $\mathrm{D}$ & $\mathrm{E}$ & $\mathrm{F}$ & $\mathrm{F}$ & $\mathrm{F}$ & $\mathrm{F}$ \\
\hline CV (\%) & 47,5 & 29,9 & 18,5 & 28,5 & 72,6 & 61,0 & 55,0 & CV (\%) & 47,5 & 29,5 & 17,1 & 13,8 & 13,8 & 14,0 & 14,2 \\
\hline
\end{tabular}

(1) The letters follow the order in which the points appear in the graphic in a top down direction, that is: the first line in the table refers to the highest points in the graphic of the collection days. The same letters on the same column did not differ significantly from each other, according to the Duncan test at $\mathrm{p} \leq 0.05$.

Figure 4. N-NH 3 Daily Volatilization Rate (DVR) (a) and $\mathrm{N}^{-\mathrm{NH}_{3}}$ Accumulated Volatilization Rate (AVR) (b) based on the treatments applied in the second side-dressing fertilization, 52 days after corn emergence.

differed between them selves in $\mathrm{N}-\mathrm{NH}_{3}$ accumulation throughout the whole period evaluated, and they also differed from the other treatments for presenting higher rates of $\mathrm{N}$. It is important to highlight that T6 treatment did not differ from T2 treatment in the first three evaluations, demonstrating again the urease inhibitor effect.

The daily rates of the sum of the two side-dressing fertilizations (Figure 5a) showed that on the second day after the application, there was $\mathrm{N}$ volatilization by $17 \%$ of the amount applied in T3 treatment. That demonstrates the high influence that temperature and moisture exert on urea hydrolysis, as it has been discussed previously regarding figures $3 \mathrm{a}$ and $4 \mathrm{a}$.

Up to the fifth day of ammonia collection, the $\mathrm{N}$ loss in T3 treatment was statistically different from the other treatments. The T6 treatment had its volatilization peak on the third day, volatilizing $7.5 \%$ of the applied $\mathrm{N}$, thus demonstrating the slower and more gradual liberation of N. From the fifth day on there was a considerable decrease in ammonia volatilization in T3 treatment, demonstrating the high degree of common urea volatilization in the first days after its application.

The amount of $52 \mathrm{~kg}$ (65\% of $\mathrm{N}$ applied in T3 treatment) was volatilized until the $11^{\text {th }}$ day, statistically differing from the other treatments. This result demonstrated that more than half of the $\mathrm{N}$ applied was lost, that is, there was no corn utilization (Figure 5b).
The treatment T5 volatilized $44 \%$ of the N applied, differing statistically from the other treatments regarding the accumulated $\mathrm{N}$ until the seventh day of collection. From the ninth day on, that treatment did not differ from T6 treatment, which volatilized $35 \%$ of the $\mathrm{N}$ applied, but with a higher volatilization in the last days of collection. These two volatilization reducers (polymers and urease inhibitor) showed themselves efficient, decreasing $\mathrm{N}-\mathrm{NH}_{3}$ losses by volatilization.

Leaf $\mathrm{N}$ concentration was higher in $\mathrm{T} 5$ treatment (Table 1), probably due to one of the lowest $\mathrm{N}$ losses by volatilization, showing the polymer use efficiency as urea volatilization inhibitor, associated to the highest rate in that treatment $\left(80 \mathrm{~kg} \mathrm{ha}^{-1} \mathrm{~N}\right)$. The other macronutrients did not differ based on the treatments.

That result corroborates the ones obtained by Barth et al. (2006), in a study about unburned sugarcane straw, who observed $\mathrm{N}-\mathrm{NH}_{3}$ losses by $24 \%$ of the $\mathrm{N}$ applied as urea and by $10 \%$ of the $\mathrm{N}$ applied as urea + polymers, which results in $\mathrm{N}$ losses reduction by $50 \%$ with the use of the inhibitor.

Similar results were also found by Cantarella \& Marcelino (2007), who showed the reduction of losses by urea $\mathrm{N}$ volatilization in 12 field experiments with corn, sugarcane and pastures.

The treatment T3 (Table 2) differed statistically from the other treatments, demonstrating the intense urease activity. As soon as urea is applied on the soil, 
(a)

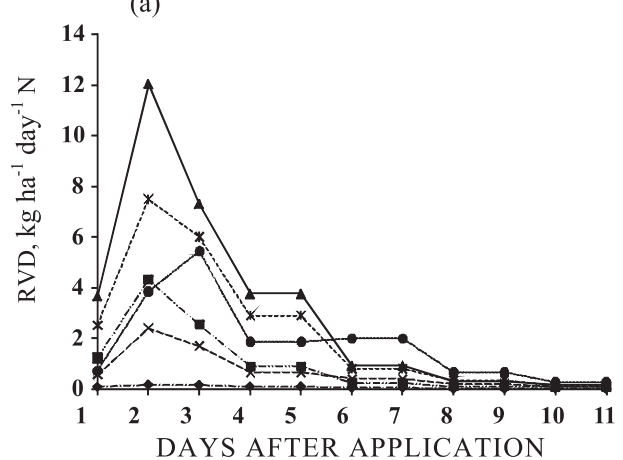

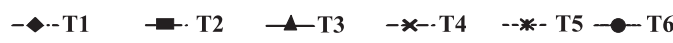

(b)

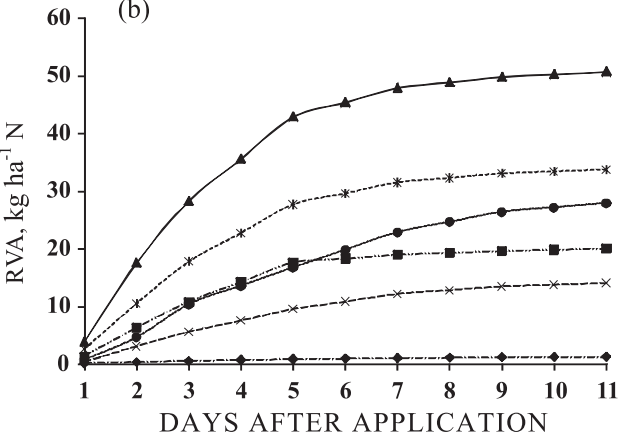

\begin{tabular}{llllllll}
\hline Day & 1 & 2 & 3 & 5 & 7 & 9 & 11 \\
& A & A & A & A & A & A & A \\
& B & B & B & B & B & B & B \\
& C & C & C & C & C & B & B \\
& CD & C & C & C & CD & C & C \\
& CD & CD & D & D & D & C & C \\
& D & D & E & E & E & D & D \\
CV $(\%)$ & 45,0 & 28,9 & 18,5 & 13,4 & 14,8 & 16,4 & 17,1
\end{tabular}

(1) The letters follow the order in which the points appear in the graphic in a top down direction, that is: the first line in the table refers to the highest points in the graphic of the collection days. The same letters on the same column did not differ significantly from each other, according to the Duncan test at $\mathrm{p} \leq 0.05$.

Figure 5. Sum of the two side-dressing fertilizations in $\mathrm{N}_{-} \mathrm{NH}_{3}$ Daily Volatilization Rate (DVR) (a) and N-NH 3 Accumulated Volatilization Rate (AVR) (b) based on the treatments applied.

Table 1. Corn leaf nutrient concentration 85 days after sowing

\begin{tabular}{|c|c|c|c|c|c|c|c|c|c|c|}
\hline \multirow{2}{*}{$\begin{array}{c}\text { Treatment } \\
\text { T1 }\end{array}$} & \multicolumn{2}{|l|}{$\mathbf{N}$} & \multicolumn{2}{|l|}{$\mathbf{P}$} & \multicolumn{2}{|l|}{$\mathbf{K}$} & \multicolumn{2}{|l|}{$\mathbf{C a}$} & \multicolumn{2}{|l|}{ Mg } \\
\hline & 26.00 & $\mathrm{C}$ & 27.97 & $\mathrm{~A}$ & 40.42 & $\mathrm{~A}$ & 5.57 & $\mathrm{~A}$ & 1.77 & A \\
\hline $\mathrm{T} 2$ & 26.95 & $\mathrm{BC}$ & 31.69 & $\mathrm{~A}$ & 45.34 & $\mathrm{~A}$ & 5.21 & $\mathrm{~A}$ & 1.71 & A \\
\hline $\mathrm{T} 3$ & 28.01 & $\mathrm{AB}$ & 30.49 & $\mathrm{~A}$ & 43.63 & $\mathrm{~A}$ & 5.45 & $\mathrm{~A}$ & 2.05 & A \\
\hline $\mathrm{T} 4$ & 27.57 & $\mathrm{ABC}$ & 33.10 & $\mathrm{~A}$ & 38.29 & $\mathrm{~A}$ & 5.67 & $\mathrm{~A}$ & 1.98 & A \\
\hline $\mathrm{T} 5$ & 29.53 & $\mathrm{~A}$ & 33.47 & $\mathrm{~A}$ & 38.71 & $\mathrm{~A}$ & 5.88 & $\mathrm{~A}$ & 2.05 & A \\
\hline $\mathrm{T} 6$ & 28.38 & $\mathrm{AB}$ & 33.91 & $\mathrm{~A}$ & 40.85 & $\mathrm{~A}$ & 5.62 & $\mathrm{~A}$ & 2.00 & A \\
\hline CV (\%) & 5.99 & & 7.10 & & 12.61 & & 6.52 & & 10.00 & \\
\hline
\end{tabular}

(1) The averages followed by the same letters on the same column did not differ from each other, according to the Duncan test at $\mathrm{p} \leq 0.05$.

it gets in contact with soil microorganisms and is fastly transforms into $2 \mathrm{NH}_{4}{ }^{+}$and $\mathrm{CO}_{3}{ }^{2-}$ by the action of the enzyme urease present in the soil. In the first soil collection, T6 and T1 treatments provided the lowest enzyme activity, demonstrating that the urease inhibitor occupies the urease active site, inactivating the enzyme. In the first soil collection after the sidedressing application, there was a significant difference between T3 (urea, $80 \mathrm{~kg} \mathrm{ha}^{-1} \mathrm{~N}$ ) and the other treatments, emphasizing the polymers and urease inhibitor efficiency at rates of $80 \mathrm{~kg} \mathrm{ha}^{-1}$.
According to Mobley \& Hausinger (1989), the inhibitor occupies the urease active site and inactivates the enzyme. Therefore it postponed the process beginning and reduces the $\mathrm{N}-\mathrm{NH}_{3}$ volatilization speed extent. Delay in hydrolysis reduces the $\mathrm{N}-\mathrm{NH}_{3}$ concentration present on the soil surface, decreases the $\mathrm{N}-\mathrm{NH}_{3}$ volatilization potential and allows for the replacement of urea into deeper horizons in the soil (Christianson et al., 1990). Another laboratory study, carried out by Antisari et al. (1996), evidenced the inverse relationship between the urease inhibitor 
(NBPT) and urea hydrolysis speed, $\mathrm{N}-\mathrm{NH}_{3}$ volatilization and $\mathrm{N}$ mineralization.

Byrnes (2000) also corroborates the results in this paper, when the author informs that urea applied to the soil is fastly hydrolyzed in two or three days, and the hydrolysis rates depend on soil temperature, moisture, and the amount and form of the application. The advantage in applying urea with urease inhibitor is that the inhibitor delays the urea hydrolysis because it occupies the urease active site and inactivates the enzyme, delaying the process beginning and reducing the $\mathrm{N}-\mathrm{NH}_{3}$ volatilization speed extent. Thus, the fertilizer might stay longer in the soil waiting for the rain, for instance, so that it might be replaced into deeper horizons in the soil.

In table 3 , it is possible to notice that $\mathrm{T} 6$ treatment was the one which responded best to the $\mathrm{N}$ application.
Its production was the highest among the treatments, differing from T1 (without fertilizer) and T2 (urea, $40 \mathrm{~kg} \mathrm{ha}^{-1} \mathrm{~N}$ ). In the other treatments, it was not observed any statistical differences for corn productivity. The T4 treatment (polymer coated urea $40 \mathrm{~kg} \mathrm{ha}^{-1} \mathrm{~N}$ ) did not differ significantly from T6 (urea, with the urease inhibitor $\mathrm{N}, 80 \mathrm{~kg} \mathrm{ha}^{-1} \mathrm{~N}$ ) as T2 treatment, demonstrating better efficiency of this fertilizer when compared to common urea.

First ear insertion height in $\mathrm{T} 1$ treatment was lower than in the other treatments, but it differed statistically only from T2 and T4 treatments. As for the factor 100 grains weight, T1 treatment also presented the lowest values and differed from $\mathrm{T} 2$ and T5 treatments, being the latter the one which presented the best result. Concerning the average ear size, there were no significant differences among the treatments.

Table 2. Soil urease activity after the treatments application in the second side-dressing fertilization

\begin{tabular}{|c|c|c|c|}
\hline Treatment & $\begin{array}{c}1^{\text {st }} \text { collection } \\
1^{\text {st }} \text { day }\end{array}$ & $\begin{array}{c}2^{\text {nd }} \text { collection } \\
3^{\text {rd }} \text { day }\end{array}$ & $\begin{array}{c}3^{\text {rd }} \text { collection } \\
5^{\text {th }} \text { day }\end{array}$ \\
\hline $\mathrm{T} 1$ & $1.9 \mathrm{~B}$ & $1.9 \mathrm{~A}$ & $2.2 \mathrm{~A}$ \\
\hline $\mathrm{T} 2$ & $2.5 \mathrm{~B}$ & $2.2 \mathrm{~A}$ & $1.9 \mathrm{~A}$ \\
\hline $\mathrm{T} 3$ & $4.2 \mathrm{~A}$ & $3.6 \mathrm{~A}$ & $2.4 \mathrm{~A}$ \\
\hline $\mathrm{T} 4$ & $2.0 \mathrm{~B}$ & $2.2 \mathrm{~A}$ & $2.2 \mathrm{~A}$ \\
\hline $\mathrm{T} 5$ & $2.2 \mathrm{~B}$ & $2.5 \mathrm{~A}$ & $2.8 \mathrm{~A}$ \\
\hline $\mathrm{T} 6$ & $1.9 \mathrm{~B}$ & $3.2 \mathrm{~A}$ & $2.3 \mathrm{~A}$ \\
\hline CV (\%) & 29.9 & 42.4 & 15.7 \\
\hline
\end{tabular}

(1) The averages followed by the same letters on the same column did not differ from each other, according to the Duncan test at $\mathrm{p} \leq 0.05$.

Table 3. Productivity, 100 grains weight, first ear insertion height and average ear size based on the treatments in the corn crop harvested after 124 days

\begin{tabular}{ccccc}
\hline Treatment & Productivity & $\mathbf{1 0 0}$ grains weight & First ear insertion height & Average ear size \\
\hline & kg ha $^{-1}$ & $\mathrm{~g}$ & $\mathrm{~cm}$ & $\mathrm{Mm}$ \\
$\mathrm{T} 1$ & $6298 \mathrm{~B}$ & $30.8 \mathrm{~B}$ & $110.2 \mathrm{~B}$ & $156.7 \mathrm{~A}$ \\
$\mathrm{~T} 2$ & $6335 \mathrm{~B}$ & $34.7 \mathrm{~A}$ & $120.1 \mathrm{~A}$ & $169.4 \mathrm{~A}$ \\
T3 & $7052 \mathrm{AB}$ & $33.5 \mathrm{AB}$ & $114.1 \mathrm{AB}$ & $169.5 \mathrm{~A}$ \\
T4 & $6947 \mathrm{AB}$ & $32.4 \mathrm{AB}$ & $119.0 \mathrm{~A}$ & $170.0 \mathrm{~A}$ \\
T5 & $7119 \mathrm{AB}$ & $35.5 \mathrm{~A}$ & $117.8 \mathrm{AB}$ & $165.6 \mathrm{~A}$ \\
T6 & $7515 \mathrm{~A}$ & $33.1 \mathrm{AB}$ & $116.5 \mathrm{AB}$ & $170.4 \mathrm{~A}$ \\
\hline
\end{tabular}

(1) The averages followed by the same letters on the same column did not differ from each other, according to the Duncan test at $\mathrm{p} \leq 0.05$. 


\section{CONCLUSIONS}

1. Polymer coated urea and urease inhibitortreated urea have demonstrated to be efficient in reducing urea $\mathrm{N}$ volatilization in side-dressing fertilization.

2. Temperature and moisture were determinant factors in urea $\mathrm{N}$ volatilization.

\section{ACKNOWLEDGEMENTS}

The authors are grateful to CAPES for financial support offering a Master's scholarship from March 2006 to February 2008.

\section{LITERATURE CITED}

ANTISARI, L.V.; MARZADORI, C.; GIOACCHINI, P.; RICCI, S. \& GESSA, C. Effects of the urease inhibitor N-(nbutyl) phosphorothioic triamide in low concentrations on ammonia volatilization and evolution of mineral nitrogen. Biol. Fert. Soils. 22:196-201,1996.

BARTH, G.; VITTI, G.C.; CANTARELLA, H. \& VITTI, A.C. Volatilização de $\mathrm{N}-\mathrm{NH}_{3}$ quanto as fontes e doses de nitrogênio aplicadas sobre a palhada de cana-de-açúcar. In: FERTIBIO 2006, Bonito, 2006. Anais. Campinas, Sociedade Brasileira de Ciência do Solo, 2006. CD ROM.

BENNETT, E. Slow-release fertilizers. Virginia Gardener Newsl., v.11, 1996. Disponível em: <www.ext.vt.edu/ departments/envirohort/articles/misc/slowrels.html> Acesso em: 26 de mar. de 2009.

BYRNES, B.H. Liquid fertilizers and nitrogen solutions. In: INTERNATIONAL FERTILIZER DEVELOPMENT CENTER. Fertilizer manual. Alabama, Kluwer Academic, 2000. p.20-44.

CANTARELLA, H. \& MARCELINO, R. O uso de inibidor de urease para aumentar a eficiência da uréia. In: SIMPÓSIO SOBRE INFORMAÇÕES RECENTES PARA OTIMIZAÇÃO DA PRODUÇ̃̃O AGRÍCOLA, Piracicaba, 2007. Anais. Piracicaba, International Plant Nutrition Institute, 2007. v.1. p.2-19.

CANTARELLA, H.; ROSSETO, R.; BARBOSA, W.; PENNA, M.J. \& RESENDE, L.C.L. Perdas de nitrogênio por volatilização da amônia e resposta da cana-de-açúcar à adubação nitrogenada, em sistema de colheita de cana sem queima prévia. In: CONGRESSO NACIONAL DA STAB, 7., Londrina, 1999. Anais. Piracicaba, Sociedade dos Técnicos Açucareiros e Alcooleiros do Brasil, 1999. p.82-87.

CANTARELLA, H. \& RAIJ, B.van. Adubação nitrogenada no Estado de São Paulo. In: SANTANA, M.B.M., coord. Adubação nitrogenada no Brasil. Ilhéus, CEPLAC, Sociedade Brasileira de Ciências do Solo, 1986. p.47-49.
COMPANHIA NACIONAL DE ABASTECIMENTO - CONAB. Acompanhamento da Safra Brasileira: Grãos - intenção de plantio segundo levantamento, novembro 2007. 2007. $27 \mathrm{p}$.

CONTIN, T.L.M. Uréia tratada com o inibidor da urease NBPT na adubação de cana-de-açúcar colhida sem despalha a fogo. Campinas, Instituto Agronômico de Campinas, 2007. 69p. (Tese de Mestrado)

COSTA, M.C.G.; VITTI, G.C. \& CANTARELLA, H. Volatilização de $\mathrm{N}-\mathrm{NH}_{3}$ de fontes nitrogenadas em cana-de-açúcar colhida sem despalha a fogo. R. Bras. Ci. Solo, 27:631637, 2003.

CHRISTIANSON, C.B.; BYRNES, B.H. \& CARMONA, G. A comparison of the sulfur and oxygen analogs of phosphoric triamide urease inhibitors in reducing urea hydrolysis and ammonia volatilization. Fert. Res., 26:21-27, 1990.

FRENEY, J.R.; LEUNING, R.; SIMPSON, J.R.; DENMEAD, O.T. \& MUIRHEAD, W.A. Estimating ammonia volatilization from flooded rice fields by simplified methods. Soil Sci. Soc. Am. J., 49:1049-1054, 1985.

HARGROVE, W.L. Soil, environmental and management factors influencing ammonia volatilization under field conditions. In: BOCK, B.R. \& KISSEL, D.E., eds. Ammonia volatilization from urea fertilizers. Alabama, NFDC, TVA, 1988. p.17-36.

LARA CABEZAS, W.A.R.; TRIVELIN, P.C.O.; BENDASSOLLI, J.A. \& GASCHO, G.J. Calibration of a semi-open static collector for determination of ammonia volatilization from nitrogen fertilizers. Comm. Soil Sci. Plant Anal., 30:389406, 1999

MALAVOLTA, E. Manual de nutrição mineral de plantas. São Paulo, Livroceres, 2006. 638p.

MALAVOLTA, E.; VITTI, G.C. \& OLIVEIRA, S.A. Avaliação do estado nutricional das plantas: Princípios e aplicações. Piracicaba, Potafos, 1997. 201p.

MELGAR, R.; CAMOZZI, M.E. \& FIGUEROA, M.M. Guia de fertilizantes, enmiendas y productos nutricionales. Buenos Aires, Instituto Nacional de Tecnologia Agropecuária, 1999. p.13-25.

MOBLEY, H.L.T. \& HAUSINGER, R.P. Microbial ureases: Significant, regulation, and molecular characterization. Microbiol. Rev., 53:85-108, 1989.

OLIVEIRA, P.P.A.; TRIVELIN, P.C.O. \& OLIVEIRA, W.S. Balanço do nitrogênio $\left({ }^{15} \mathrm{~N}\right)$ da ureia nos componentes de uma pastagem de capim-marandu sob recuperação em diferentes épocas de calagem. R. Bras. Zootec., 36:19821989, 2007.

PRIMAVESI, O.; CORRÊA, L.A.; PRIMAVESI, A.C. \& CANTARELLA, H. Adubação com uréia em pastagem de Cynodon dactylon cv. Coastcross sob manejo rotacionado: Eficiência e perdas. São Carlos, Embrapa Pecuária Sudeste, 2001. 42p. (Circular Técnica, 30) 
REIS Jr., R.A. KimCoat - uma nova ferramenta para otimização do uso de fertilizantes. Inf. Agron., 117:13-14, 2007.

TABATABAI, M.A. \& BREMNER, J.M. Assay of urease activity in soil. Soil Biol. Biochem., 4:479-487, 1972.
TEDESCO, M.J.; GIANELLO, C.; BISSANI, C.A. \& BOHNEN, S.J. Análise de solo, plantas e outros materiais. 2.ed. Porto Alegre, Universidade Federal do Rio Grande do Sul, 1995. 147p. (Boletim Técnico, 5)

WHITEHEAD, D.C. Grassland nitrogen. Wallingford, CAB International, 1995. 352p. 